\title{
Effect of graded levels of zinc and boron on nutrient content and uptake by grain and straw of paddy
}

\section{M.B. MAHENDRA KUMAR, C. T. SUBBARAYAPPA AND V. RAMAMURTHY}

Received : 22.09.2017; Revised : 08.11.2017; Accepted : 18.11.2017

\section{MEMBERS OF RESEARCH FORUM:}

Corresponding author : M.B. MAHENDRA KUMAR, Department of Soil Science and Agricultural Chemistry, University of Agricultural Sciences, GKVK, BENGALURU (KARNATAKA) INDIA

Co-authors :

\section{T. SUBBARAYAPPA,}

Department of Soil Science and Agricultural Chemistry, University of Agricultural Sciences, GKVK, BENGALURU (KARNATAKA) INDIA

V. RAMAMURTHY, ICAR-National Bureau of Soil Survey and Land Use Planning, Hebbal Regional Centre, BENGALURU (KARNATAKA) INDIA

\section{Summary}

A field experiment was taken during summer at Naganahalli village, Mysore district, Karnataka to study the graded levels of zinc and boron on nutrient content and uptake by grain and straw of paddy. Among the treatments, $\mathrm{T}_{12}$ treatment $\left(\mathrm{RDF}+\mathrm{ZnSO}_{4} @ 20 \mathrm{~kg} \mathrm{ha}^{-1}+\right.$ borax @ 4 $\mathrm{kg} \mathrm{ha}^{-1}$ ) recorded significantly higher nutrients $(\mathrm{N}, \mathrm{P}, \mathrm{Ca}, \mathrm{Mg}, \mathrm{Zn}, \mathrm{Cu}$ and $\mathrm{B})$ content and uptake by grain and straw of paddy compared to all other treatments. The potassium and sulphur content and uptake were significantly high in $\mathrm{T}_{16}$ treatment $\left(\mathrm{RDF}+\mathrm{ZnSO}_{4} @ 30 \mathrm{~kg}\right.$ ha $^{-1}+$ borax @6 $\mathrm{kg} \mathrm{ha}^{-1}$ ) but, the potassium uptake was significantly high in $\mathrm{T}_{13}$ treatment $\left(\mathrm{RDF}+\mathrm{ZnSO}_{4} @ 20 \mathrm{~kg} \mathrm{ha}^{-1}+\right.$ borax @ $\left.6 \mathrm{~kg} \mathrm{ha}^{-1}\right)$. The RDF+FYM $\left(\mathrm{T}_{1}\right)$ treatment showed significantly higher Fe and Mn content but their uptake was significantly high in $\mathrm{T}_{12}(\mathrm{RDF}+$ $\mathrm{ZnSO}_{4} @ 20 \mathrm{~kg} \mathrm{ha}^{-1}+$ borax @ $\left.4 \mathrm{~kg} \mathrm{ha}^{-1}\right)$ and $\mathrm{T}_{3}\left(\mathrm{RDF}+\mathrm{ZnSO}_{4} @ 20 \mathrm{~kg} \mathrm{ha}^{-1}\right)$ treatment by grain and straw of paddy.

Key words : Content, Uptake, Grain, Straw, Treatment, Significantly

How to cite this article : Kumar, M.B. Mahendra, Subbarayappa, C.T. and Ramamurthy, V. (2017). Effect of graded levels of zinc and boron on nutrient content and uptake by grain and straw of paddy. Asian J. Soil Sci., 12 (2) : 275-282 : DOI : 10.15740/HAS/AJSS/12.2/275-282. 